\title{
Review
}

\section{Comparative study of Silver Sulfadiazine with other materials for healing and infection prevention in burns: A systematic review and meta-analysis}

\author{
Heloisa Helena Nímia ${ }^{a}$, Viviane Fernandes Carvalho ${ }^{a}$, Cesar Isaac ${ }^{b}$, \\ Francisley Ávila Souza ${ }^{c}$, Rolf Gemperli ${ }^{b}$, André Oliveira Paggiaro ${ }^{a, *}$ \\ a Guarulhos University, Nursing Post, Graduation Program, Praça Tereza Cristina, 88, Centro, Guarulhos, SP, \\ 07020-071, Brazil \\ b São Paulo University, Plastic Surgery Division, Av. Dr. Arnaldo, 455, Cerqueira César, São Paulo, SP, 01246-903, \\ Brazil \\ ${ }^{\mathrm{c}}$ Dentistry College, UNESP, Rua José Bonifácio, 1193, Araçatuba, São Paulo, SP, 16015-050, Brazil
}

\section{A R T I C L E I N F O}

Article history:

Accepted 17 May 2018

Keywords:

Burns

Silver Sulfadiazine

Wound healing

Infection

Occlusive dressings

\begin{abstract}
A B S T R A C T
The aim of this systematic review with meta-analysis was to compare the effect of Silver Sulfadiazine (SSD) with other new dressings, with or without silver, on healing and infection prevention in burns. The electronic search was carried out in the electronic databases of Pubmed,ScienceDirect, Lilacs and BVS. The articles included were randomized clinical trials about burn treatment with SSD, which evaluated the healing and infection of burn wounds in humans. The exclusion criteria included articles, editorials and letters published in the form of abstracts, unpublished reports and case series, cross-sectional, observational experimental studies, and the use of sulfadiazine for other types of wounds. The search identified 873 references, and 24 studies were included in accordance with the eligibility criteria. The results showed a statistically favorable difference related to the time of healing for silver dressings ( $p<0.0001$; MD 3.83; 95\% CI 2.03-5.62) and dressings without silver $(\mathrm{p}<0.007$; MD 2.9; $95 \%$ CI 0.815 .00 ) in comparison with SSD. The rate of infection showed no difference in the group treated with SSD compared with the group treated with dressings containing silver $(p>0.05)$. The rate of infection was significantly higher in the SSD group compared with the group treated with dressings without silver ( $p<0.005$; MD 25.29\% and MD 12.97\%). Considering the clinical trials conducted up to the present time, the authors concluded that new dressings with and without silver show better results than SSD for wound healing, and burns treated with dressings without silver are less likely to become infected than burns with SSD. No differences between SSD and new silver materials were observed in relation to infection prevention.
\end{abstract}

(c) 2018 Elsevier Ltd and ISBI. All rights reserved.

\footnotetext{
* Corresponding author at: R. Dr. Rubens Meirelles, 105, AP 54 M, Barra Funda, Cep 01141-000, Brazil

E-mail addresses: helonimia@pucpcaldas.br (H.H. Nímia), vcarvalho@prof.ung.br (V.F. Carvalho), cesar.isaac@hc.fm.usp.br (C. Isaac), f.avilasouza@foa.unesp.br (F.Á. Souza), rolf.gemperli@hc.fm.usp.br (R. Gemperli), apaggiaro@prof.ung.br (A.O. Paggiaro).

https://doi.org/10.1016/j.burns.2018.05.014

0305-4179/@ 2018 Elsevier Ltd and ISBI. All rights reserved.
} 


\section{Contents}

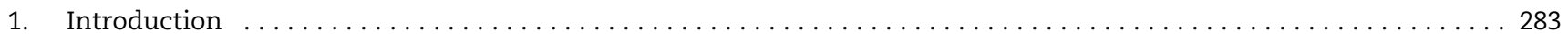

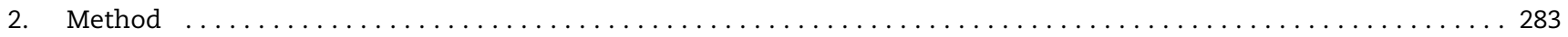

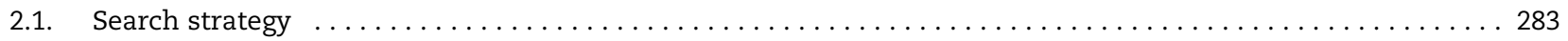

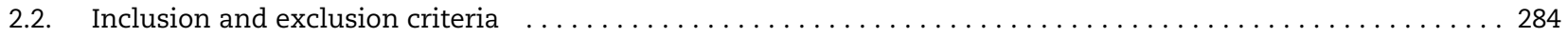

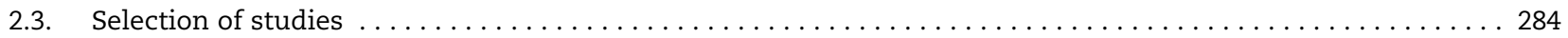

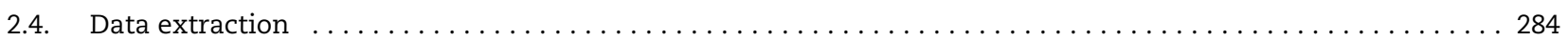

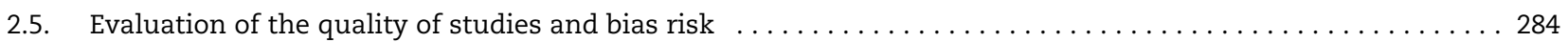

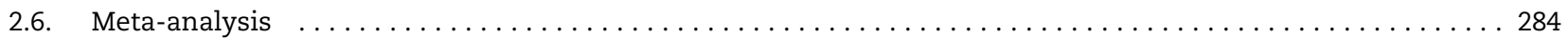

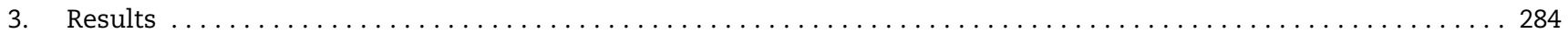

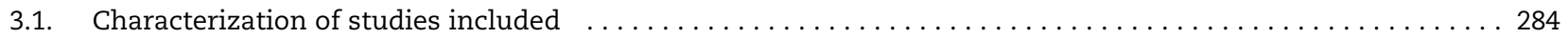

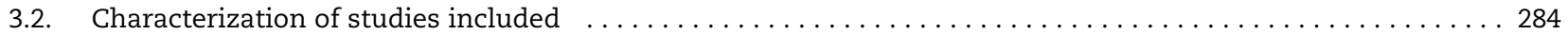

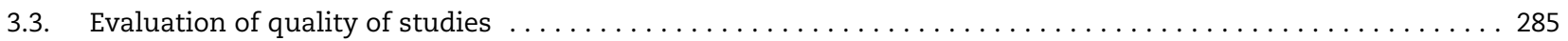

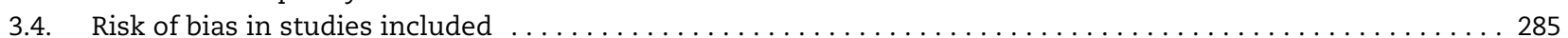

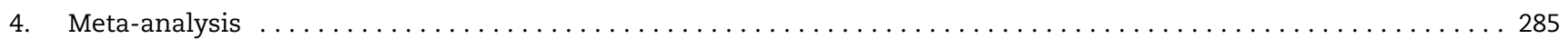

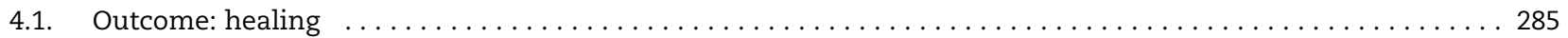

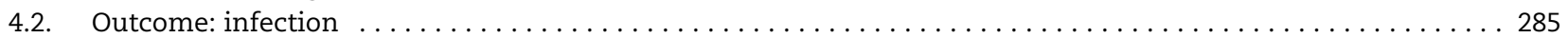

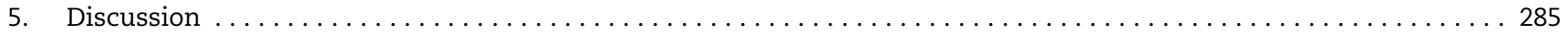

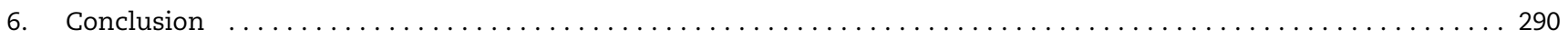

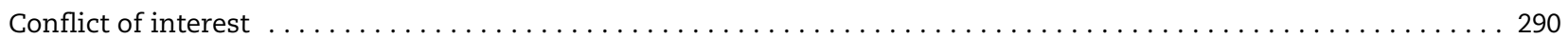

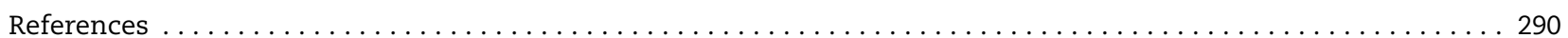

\section{Introduction}

Burns are defined as organic tissue lesions resulting from some trauma of thermal, electrical, radioactive or chemical origin, promoting tissue destruction by protein denaturation and/or ionization of cell content [1].

Definition of the best treatment is based on the evaluation of multiple variables, such as depth, extension, localization of the burn, age of the patient, presence or absence of inhalation injury, electrical burn, associated trauma, and pre-existing diseases [2]. In clinical treatment topical agents have been used, the majority of these being antimicrobial agents [3]. Among them, Silver Sulfadiazine (SSD) is frequently used because it is easy to apply, low cost, and painless. It is widely used for treating second- and third-degree burns [4].

In 2010, the Cochrane Wounds Group published a systematic review emphasizing the lack of evidence for the effects of dressings with silver on the prevention of infection and healing of wounds in general, including burns [5]. With regard to burns, no beneficial effect of SSD was shown for the prevention of infection of wounds in patients with partial thickness burns. Hussain and Ferguson pointed out that although there was evidence of the antimicrobial effect, there was no direct evidence of prevention of infection and reported the occurrence of delay in the healing process [6].

These silver agents, which are toxic to bacterial cells, may also affect the cells of the skin itself and delay healing, and SSD is known to be capable of retarding the growth of keratinocytes and fibroblasts [7]. Recent discoveries have indicated that compounds containing silver delay the wound-healing process, and that silver may have severe cytotoxic activity in various host cells [8]. As a metal, silver is relatively inert, but once it is ionized by fluids, it becomes highly reactive, and binds to the proteins of cell membranes, leading to cellular denaturation and mitochondrial dysfunction in a large number of the cells, similar to events that occur in the cells of invading microorganisms [7]. Irrespective of the vehicle for the release of silver (solutions, creams, ointments, or in nanocrystalline form), it is highly toxic both to keratinocytes and fibroblasts [7]. Therefore, in spite of SSD being used on a large scale by the majority of burn treatment centers, we still have no definite answer about its effect on the prevention of infections and the promotion of the healing process, in comparison with other dressings containing silver or not.

In view of the aforementioned information, the aim of the present study was to conduct a systematic review with metaanalysis, to compare the effect of SSD with other materials, with or without silver, for the topical treatment of second- and third-degree burns in relation to wound healing and infection prevention.

\section{2. $\quad$ Method}

This was a systematic review with meta-analysis, using the Preferred Reporting Items for Systematic Reviews and Metaanalyses (PRISMA) checklist for control [9].

\subsection{Search strategy}

To studies, searches were made for articles published and indexed in the electronic databases of Pubmed, ScienceDirect, BVS, and Lilacs. A specific research question was formulated, based on the population, intervention, control, and results (PICO) [10], serving to determine the MeSHs used in the search. Two different outcomes were evaluated: healing and prevention of infection. We asked the following question, "What are the effects of SSD in comparison with other materials, with or without silver, on the topical treatment of second- and third- 
degree burns in relation to wound healing and infection prevention?".

Therefore:

P (population) - Burns

I (intervention) - Silver Sulfadiazine

C (control) - This item was not included in the research strategy to increase the number of articles selected.

o (outcome) - Infection control or wound healing

\subsection{Inclusion and exclusion criteria}

The following criteria were established to guide the inclusion of articles: studies were randomized clinical trials (RCT) investigating the treatment of burns with SSD which evaluated the healing and infection of wounds in humans; full articles published in national and international periodicals; indexed in the Lilacs, ScienceDirect, BVS, and Pubmed electronic databases from 2000 to 2016; and published in Portuguese, English, or Spanish. The following exclusion criteria were established: articles, editorials, and letters published in the form of abstracts, unpublished studies, case reports, case series, cross-sectional, observational, and experimental studies, and those in animals. In addition we excluded studies which used SSD for any other type of wound, or evaluated outcomes other than those established in our objective.

\subsection{Selection of studies}

Firstly, 2 independent reviewers, who were specialists in the treatment of patients with burns, read the titles and performed a triage evaluation. Considering the inclusion and exclusion criteria, these same individuals evaluated the pre-selected articles in full and determined the final sample. In case of disagreement about any article, a third specialist professional was invited to give an opinion and resolve the question.

\subsection{Data extraction}

For data extraction, a collection instrument was created comprising an identification code, source consulted, data with reference to the periodical (title, magazine, year, volume, number, page, language), researcher (name, qualification, place of work), and study (type, objectives, sample, scope, methodological design, result and conclusions). Data extracted from trials published in duplicate were included only once. Data were extracted by a single reviewer, and the accuracy verified by the second reviewer. Any discrepancy was resolved by discussion, and if necessary, a third specialist was consulted.

\subsection{Evaluation of the quality of studies and bias risk}

The article structure was evaluated with the use of the CONSORT tool, and the Cochrane Handbook criteria were used for making judgments about the risk of sample bias [11].

Consolidated Standards of Reporting Trials (CONSORT) was created by investigators and editors in the 1990s for improving the quality of reporting randomized clinical trials. The CONSORT check-list includes 22 items that evaluate the 4 stages of a clinical study: title, methods, results, and discussion [12].
The reviewers evaluated the articles by checking the 22 items of CONSORT. Each item was awarded a point between 0 and 1 , according to the following criterion: when the study did not present the information evaluated it received 0 ; if it presented the information, it received 1 point. After evaluating the individual points of each article, the points were added, and the mean and standard deviation of each article and of the final sample in each sub-item was calculated.

The risk of bias of each trial was evaluated, using the criteria described in the Cochrane Handbook for interventions of systematic reviews [11]. This tool verifies the 6 domains of risk of bias which could occur in randomized clinical trials: selection, performance, detection, friction, communication, and other biases.

\subsection{Meta-analysis}

Among the trials selected for the final sample, Silver Sulfadiazine was compared with a great many different types of dressings. Thus, 2 groups were established for grouping these dressings to enable the meta-analysis to be conducted, and 2 groups of analyses were created:

1) SSD vs dressings with silver.

2) SSD vs dressings without silver.

The meta-analysis was based on the method of inversion of variance. The number of days needed for re-epithelialization for patients using the dressings without silver versus SSD, and using dressings with silver versus SSD were the measurements of outcomes. The continuous result was evaluated by the mean difference (MD) and by the standard deviation (SD) with an interval of confidence of $95 \%$ (IC). The MD values were considered significant when $P<0.05$. The Review Manager 5 software (Cochrane Group) was used for meta-analysis.

To analyze the outcome of infection, the Student's $t$ test for independent samples was used to compare the mean values of the rates (percentage) of infection. The results were considered statistically significant for values of $p<0.05$. To analyze this outcome, 2 comparative groups were also used: SSD versus dressings with silver and SSD versus dressings without silver.

\section{Results}

\subsection{Characterization of studies included}

Initially 873 articles were found, and after reading the title and abstract, only 53 studies remained. After evaluating the texts in full, the sample consisted of 24 randomized clinical trials (Chart 1).

\subsection{Characterization of studies included}

A high proportion of the studies selected used SSD as a control group for evaluating some other type of dressing, so that in total, 20 different types of dressings were used. In all the studies, the majority of the sample was composed of patients with superficial or deep second-degree burns. There was a predominance of the adult population, and only 5 trials were 


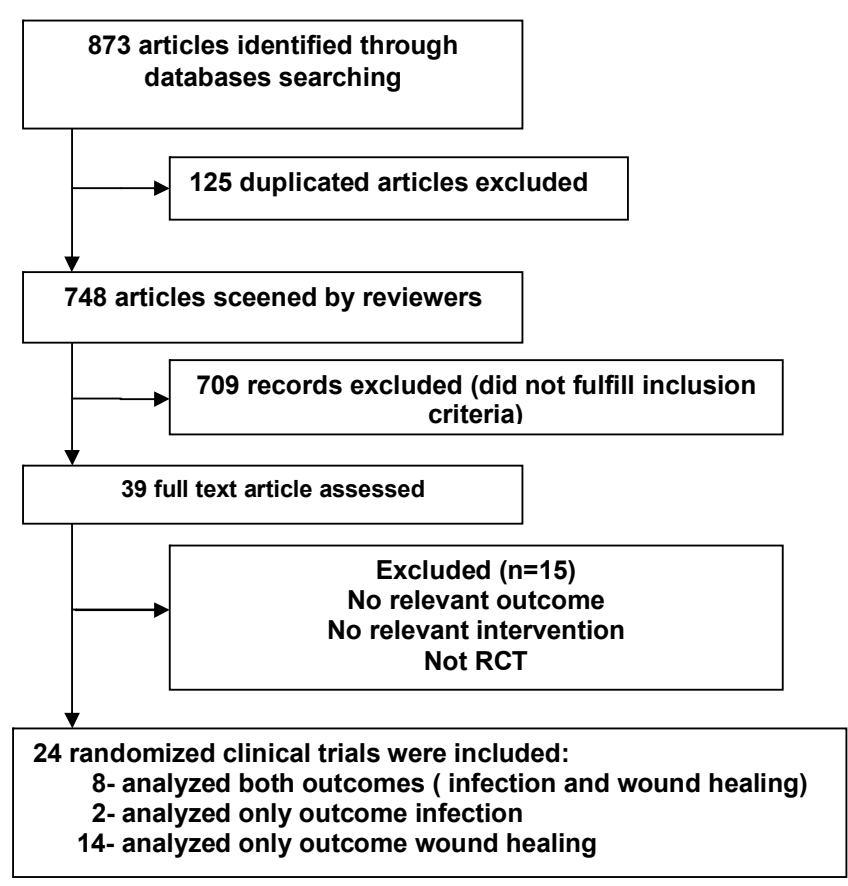

Chart 1 - Flowchart of study selection.

performed with children. Two studies evaluated only the outcome of infection, 14 studies only the outcome of healing, and eight evaluated both outcomes.

In Table 1, the characteristics of the studies selected for the final sample may be observed.

\subsection{Evaluation of quality of studies}

When the studies were evaluated by CONSORT, the values related to method (46\%) and other items of information (9\%) were the lowest values of the items checked. In the final mean value, only $52 \%$ of the items checked in the clinical trials were found.

In Table 2, we analyzed the structure of the clinical trials triaged according to CONSORT.

\subsection{Risk of bias in studies included}

In Figs. 1 and 2 we show a summary of the risk of bias evaluation based on the criteria of the Cochrane Handbook for interventions of systematic reviews [9]. In general, the methodological quality of the trials included was relatively poor, although some of them presented low risk of bias.

In the risk of bias evaluation, the Cochrane criteria indicated a high relative risk of bias in the questions related to blinding and allocation of participants (Fig. 2).

\section{Meta-analysis}

\subsection{Outcome: healing}

To perform the meta-analysis, all the articles that did not present the mean and standard deviation of the wound-healing time were excluded. Thus, of the 22 initial articles that evaluated the outcome of healing, only 9 could be used in the meta-analysis, 5 in the dressings without silver group (E2, E3, E8, E9 and E14) and 4 in the dressings with silver group (E10, E13, E16 and E19).

The random effects analysis showed a favorable statistical difference for number of days of healing for the dressings with silver in comparison with SSD ( $p<0.0001$; MD 3.83;95\% CI 2,035.62) as shown in Fig. 3.

The random effects analysis showed a favorable statistical difference for number of days of healing for the dressings without silver in comparison with dressings with SSD ( $\mathrm{p}<0.007$; MD 2.9;95\% CI 0.81-5.00) as shown in Fig. 4.

Figs. 3 and 4 represent the forest graph for presenting the result of the meta-analysis of this study.

\subsection{Outcome: infection}

The low number of articles that evaluated infection and the poor quality of the information available was deleterious to the statistical analysis of this outcome. With regard to the rate of infection, when we compared SSD with the dressings with silver (E6, E13, E15 e E19) we observed that there was no statistical difference between the 2 groups, with a mean number of samples of $11.34 \%$ and $7.35 \%$, respectively $(p=0.05)$. Whereas, in the comparison between SSD and dressings without silver (E3, E5, E9, E12, E14 and E21) we observed a lower rate of infection in patients who received dressings without silver; this result was statistically significant $(p=0.005)$ with a mean rate of $12.97 \%$ of infection versus $25.29 \%$ in patients who received SSD.

\section{Discussion}

The large number of therapeutic options for the topical treatment of burns, makes it difficult for healthcare professionals to make decisions regarding the best procedures to be adopted. In both second- and third-degree lesions, SSD continues to be the drug most frequently used by reason of its low cost and high level of availability. However, in spite of its consolidated use, we lack evidence for the efficacy of SSD compared with other new materials in preventing infection and helping the re-epithelialization of wounds [5].

Therefore, the aim of this research was to use the concepts of evidence-based practice, by conducting a systematic review with meta-analysis to try and elicit a comparison between SSD and new dressings to treat secondand third-degree burns for the prevention of infection and stimulation of re-epithelialization.

Initially 873 studies were found, however, after applying the inclusion and exclusion criteria, the sample was restricted to only 24 articles, of which 10 analyzed the outcome of infection and 22 the outcome of re-epithelialization ( 8 evaluated the 2 outcomes concomitantly). This small sample indicated that in spite of the large number of publications in the area, the quality of the studies that have been produced was extremely poor, with a predominance of case reports and a series of cases with low impact, rather than RCTs. Initially, the search period would be the last ten years of publications, but 
Table 1 - Characterization of studies included for systematic review, according to publication data.

\begin{tabular}{|c|c|c|c|c|c|c|}
\hline \multirow[t]{2}{*}{ Study } & \multirow[t]{2}{*}{ Author, source, year, country } & \multirow[t]{2}{*}{ Sample } & \multirow{2}{*}{$\begin{array}{l}\text { Characteristics of } \\
\text { the sample (mean } \\
\text { age, sex. depth) }\end{array}$} & \multirow[t]{2}{*}{ Intervention } & \multicolumn{2}{|r|}{ Outcomes } \\
\hline & & & & & $\begin{array}{l}\text { Infection } \\
\text { (rate) }\end{array}$ & $\begin{array}{c}\text { Healing } \\
\text { (mean-days/ } \\
\text { standard deviation }\end{array}$ \\
\hline E1 & $\begin{array}{l}\text { Tang et al. [13], J Trauma Acute Care } \\
\text { Surg, 2015, China }\end{array}$ & 153 patients & $\begin{array}{l}\text { 30, both, thickness } \\
\text { partial depth }\end{array}$ & Mepilex Ag $\times$ SSD & - & $\begin{array}{l}87,1 / 29 \\
85,2 / 27,8 \text { (rate) }\end{array}$ \\
\hline E2 & Glenn et al. [14], Burns, 2014, Ásia & 38 participants & $\begin{array}{l}31.5, \text { both, thickness } \\
\text { partial superficial }\end{array}$ & Petrolatum $\times$ SSD & - & $\begin{array}{l}6,2 / 2,8 \\
7,8 / 2,1\end{array}$ \\
\hline E3 & $\begin{array}{l}\text { Muhammad and Naheed [15], J Pak } \\
\text { Med Assoc, 2013, Pakistan }\end{array}$ & 50 patients & $\begin{array}{l}\text { 40, both, second } \\
\text { degree }\end{array}$ & Aloe Vera $\times$ SSD & $\begin{array}{l}25 \% \\
16 \%\end{array}$ & $\begin{array}{l}11 / 4,18 \\
24,24 / 11,16\end{array}$ \\
\hline $\mathrm{E} 4$ & $\begin{array}{l}\text { Oen et al. [16], Plastic and Recon- } \\
\text { structive Surgery, 2012, Holland }\end{array}$ & 179 patients & $\begin{array}{l}41.6, \text { both, thickness } \\
\text { partial }\end{array}$ & $\begin{array}{l}\text { Nitrato de } \\
\text { Cerium } \times \text { SSD }\end{array}$ & - & $\begin{array}{l}11 /- \\
9 /\end{array}$ \\
\hline E5 & $\begin{array}{l}\text { Ostlie et al. [17], Journal of Pediatric } \\
\text { Surgery,2012, }\end{array}$ & 100 patients & $\begin{array}{l}\text { 9, both, thickness } \\
\text { partial }\end{array}$ & Colagenase $\times$ SSD & $\begin{array}{l}14 \% \\
2 \%\end{array}$ & - \\
\hline E6 & $\begin{array}{l}\text { Silverstein et al. [18], Journal of Burn } \\
\text { Care \& Research, 2011, Estados } \\
\text { Unidos }\end{array}$ & 101 patients & $\begin{array}{l}38.35 \text {, both, thick- } \\
\text { ness partial }\end{array}$ & $\begin{array}{l}\text { Silicone } \\
\mathrm{Ag} \times \text { Coverage } \\
\mathrm{SSD}\end{array}$ & $\begin{array}{l}12.24 \% \\
15.69 \%\end{array}$ & $\begin{array}{l}17,11 /- \\
13,44 /\end{array}$ \\
\hline E7 & $\begin{array}{l}\text { Piatkowski et al. [19], Journal of } \\
\text { Burn Care \& Research, 2011, } \\
\text { Germany }\end{array}$ & 60 patients & $\begin{array}{l}40.25 \text {, both, thick- } \\
\text { ness partial }\end{array}$ & $\begin{array}{l}\text { Bio } \\
\text { Celulose } \times \text { SSD }\end{array}$ & - & $\begin{array}{l}10 /- \\
10 /\end{array}$ \\
\hline E8 & $\begin{array}{l}\text { Mostaque and Rahman [20], Journal } \\
\text { of Burn Care \& Research, } 2011\end{array}$ & 102 patients & $\begin{array}{l}3,82 \text {, both, second } \\
\text { degree superficial } \\
\text { and deep }\end{array}$ & $\begin{array}{l}\text { Human Amniotic } \\
\text { Membrane } \times \text { SSD }\end{array}$ & - & $\begin{array}{l}13.33 / 0.95 \\
14.02 / 0.96\end{array}$ \\
\hline E9 & $\begin{array}{l}\text { Malik et al. [21], International } \\
\text { Wound Journal, 2010, Pakistan }\end{array}$ & 150 patients & $\begin{array}{l}28 \text {, both, thickness } \\
\text { partial }\end{array}$ & Honey $\times$ SSD & $\begin{array}{l}8 \% \\
38.67 \%\end{array}$ & $\begin{array}{l}13.47 / 4.06 \\
15.62 / 4.4\end{array}$ \\
\hline E10 & $\begin{array}{l}\text { Muangman et al. [22], International } \\
\text { Wound Journal, 2010, }\end{array}$ & 70 patients & $\begin{array}{l}\text { 38.6, both, thickness } \\
\text { partial second degree }\end{array}$ & Aquacel $\mathrm{Ag} \times \mathrm{SSD}$ & - & $\begin{array}{l}10 / 3 \\
13.7 / 4.3\end{array}$ \\
\hline E11 & $\begin{array}{l}\text { Grippaudo et al. [23], Asian J Surg., } \\
\text { 2010, Italy }\end{array}$ & 80 patients & $\begin{array}{l}33.5, \text { both, second } \\
\text { degree }\end{array}$ & Procutase $\times$ SSD & - & $\begin{array}{l}11 /- \\
13.5 /-\end{array}$ \\
\hline E12 & $\begin{array}{l}\text { Hosseini et al. [24], Asian J Surg., } \\
\text { 2009, Iran }\end{array}$ & 76 patients & $\begin{array}{l}21.9, \text { both, thickness } \\
\text { partial }\end{array}$ & Xenoderm $\times$ SSD & $\begin{array}{l}17.9 \% \\
40.5 \%\end{array}$ & - \\
\hline E13 & $\begin{array}{l}\text { Glat et al. [25], J Burn Care Res, 2009, } \\
\text { Pennsylvania }\end{array}$ & 24 children & $\begin{array}{l}2.74 \text {, both, thickness } \\
\text { partial }\end{array}$ & SilvaSorb $\times$ SSD & $\begin{array}{l}0 \% \\
0 \%\end{array}$ & $\begin{array}{l}12.42 / 3.58 \\
12.75 / 7.47\end{array}$ \\
\hline E14 & $\begin{array}{l}\text { Hirsch et al. [26], European Journal } \\
\text { of Medical Research, 2008, Germany }\end{array}$ & 40 patients & $\begin{array}{l}42.5 \text {, both, thickness } \\
\text { partial }\end{array}$ & $\mathrm{MEBO} \times \mathrm{SSD}$ & $\begin{array}{l}0 \% \\
0 \%\end{array}$ & $\begin{array}{l}24.3 / 14.3 \\
24.8 / 18.3\end{array}$ \\
\hline E15 & $\begin{array}{l}\text { Caruso et al. [27], Journal of Burn } \\
\text { Care \& Research, 2006, } \\
\text { Pennsylvania }\end{array}$ & 82 patients & $\begin{array}{l}26.7 \text {, both, thickness } \\
\text { partial }\end{array}$ & Aquacel $\mathrm{Ag} \times \mathrm{SSD}$ & $\begin{array}{l}7.1 \% \\
5.0 \%\end{array}$ & $\begin{array}{l}31 /- \\
24 /-\end{array}$ \\
\hline E16 & $\begin{array}{l}\text { Koller [28]. Drugs Exptl.Clin. Res. } \\
\text { 2004,Slovakia }\end{array}$ & 33 patients & $\begin{array}{l}\text { 37.85, both, second } \\
\text { degree superficial }\end{array}$ & $\begin{array}{l}\text { Hyaluronic Acid } \\
\text { with } \mathrm{Ag} \times \mathrm{SSD}\end{array}$ & - & $\begin{array}{l}8.167 / 2.684 \\
13.067 / 5.203\end{array}$ \\
\hline E17 & $\begin{array}{l}\text { Carneiro et al. [29], Cent Afr J Med, } \\
\text { 2002, Tanzania }\end{array}$ & 64 children & $\begin{array}{l}2.5, \text { both, second } \\
\text { degree }\end{array}$ & Phenytoin $\times$ SSD & - & $\begin{array}{l}-L^{\mathrm{a}} \\
-L^{-}\end{array}$ \\
\hline E18 & $\begin{array}{l}\text { Scott et al. [30], The Journal of } \\
\text { Alternative and Complementary } \\
\text { Medicine, 2002, Brazil }\end{array}$ & 23 patients & $\begin{array}{l}30,-, \text { superficial sec- } \\
\text { ond degree }\end{array}$ & Propolis $\times$ SSD & - & $\begin{array}{l}9.09 /- \\
10.96 /-\end{array}$ \\
\hline E19 & Gracia [31], Burns, 2001, Philippines & 59 patients & $\begin{array}{l}\text { 27, both, thickness } \\
\text { partial }\end{array}$ & $\begin{array}{l}\text { Cerium } \\
\text { Nitrate } \times \text { SSD }\end{array}$ & $\begin{array}{l}3.33 \% \\
13.33 \%\end{array}$ & $\begin{array}{l}17.2 / 8.3 \\
25.1 / 19.4\end{array}$ \\
\hline E20 & $\begin{array}{l}\text { Lal et al. [32], Shock, 2000, United } \\
\text { States }\end{array}$ & 89 patients & $\begin{array}{l}\text { 3.1,both, second and } \\
\text { third degree }\end{array}$ & $\mathrm{MEBO} \times \mathrm{SSD}$ & - & $\begin{array}{l}-L^{\mathrm{a}} \\
--\end{array}$ \\
\hline E21 & $\begin{array}{l}\text { Barret et al. [33], Plastic Reconstr. } \\
\text { Surgery, 2000, United States }\end{array}$ & 20 patients & $\begin{array}{l}8.5 \text {, both, thickness } \\
\text { partial superficial }\end{array}$ & Biobrane $\times$ SSD & $\begin{array}{l}0 \% \\
0 \%\end{array}$ & $\begin{array}{l}9.7 / 0.7 \\
16.1 / 0.6\end{array}$ \\
\hline E22 & $\begin{array}{l}\text { Kumar et al. [34], ANZ J. Surg, 2004, } \\
\text { Australia }\end{array}$ & 33 patients & $\begin{array}{l}\text { 3.60, male, second } \\
\text { degree }\end{array}$ & $\begin{array}{l}\text { Biobra- } \\
\text { ne } \times \text { SSD } \times \text { Tran- } \\
\text { scyte }\end{array}$ & - & $\begin{array}{l}9.5 / \\
11.2 /- \\
7.5 /\end{array}$ \\
\hline E23 & Huang et al. [35], Burns, 2007 & 98 patients & $\begin{array}{l}\text { 36.81, predominantly } \\
\text { man, second degree }\end{array}$ & Acticoat $\times$ SSD & - & $\begin{array}{l}12.42 / 5,4 \\
15.79 / 5.6\end{array}$ \\
\hline E24 & $\begin{array}{l}\text { Nasiri et al. [36], Journal of Ethno- } \\
\text { pharmacology, 2016, Iran }\end{array}$ & 45 patients & $\begin{array}{l}39.9, \text { both, second } \\
\text { degree }\end{array}$ & $\begin{array}{l}\text { Arnebia } \\
\text { ointment } \times \text { SSD }\end{array}$ & - & $\begin{array}{l}13.9 / 5.3 \\
17.5 / 6.9\end{array}$ \\
\hline
\end{tabular}

\footnotetext{
${ }^{a}$ In these RCTs the data relative to wound healing were nor presented in days of healing, only as binary even healing or not.
} 


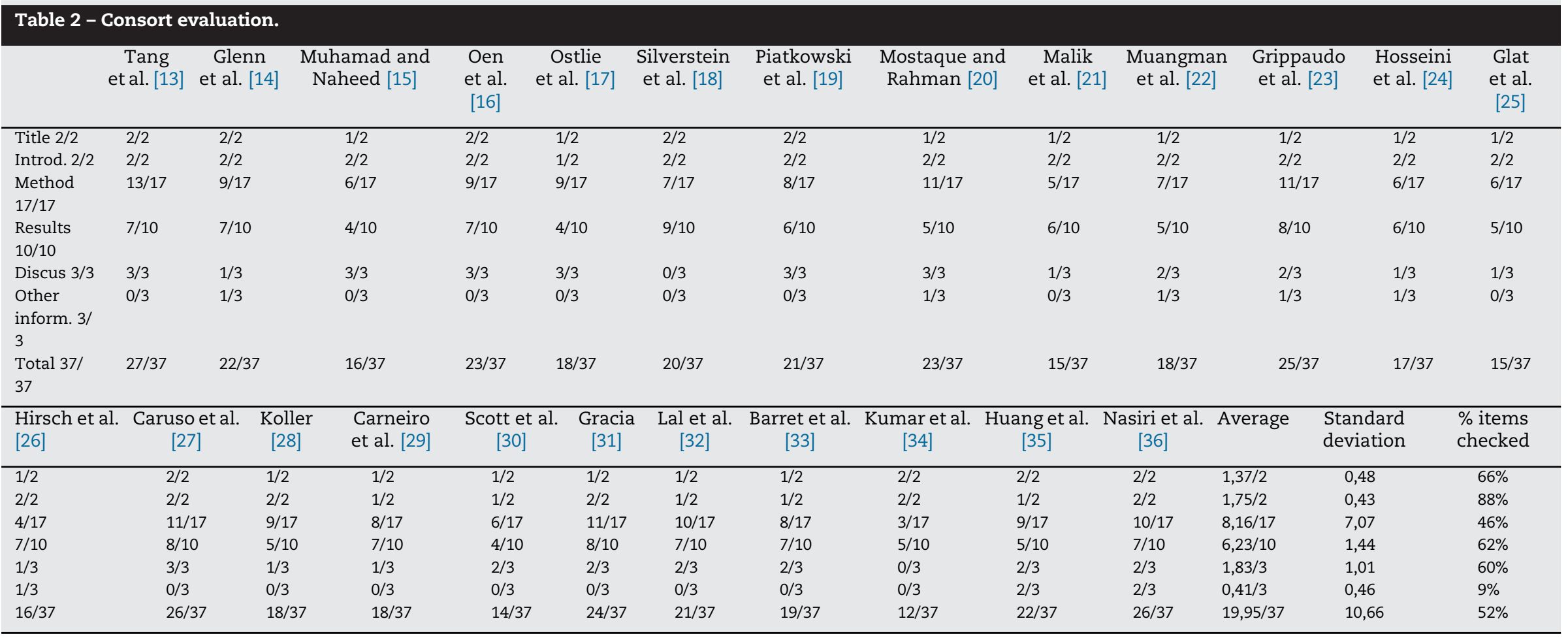




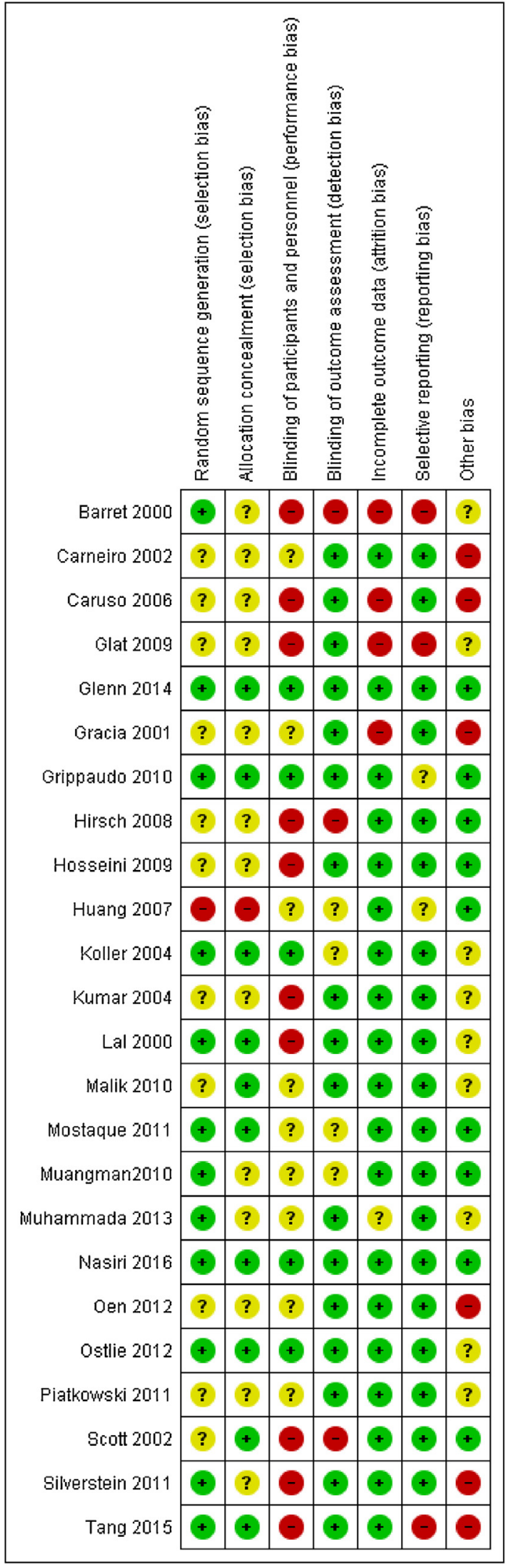

Fig. 1 - Summary of quality of risk of bias: judgment of the authors' review about each item of quality of risk included in the study. the lack of trials encouraged the authors of this study to prolong the search period (2000-2016) with a view to obtaining a higher number of RCTs.

With regard to the characteristics of the clinical studies selected, we were able to ascertain that the majority of these used patients with second-degree burns, and only 1 study also included individuals with third-degree lesions. The exclusion of these deep burns was probably due to the fact that the majority of these wounds needed skin grafts to obtain definitive coverage [37-39]. The majority of the studies were conducted with young adults of both sexes, although a few children had also been included.

In general, all the clinical trials compared SSD with some other product (20 in total), causing a great diversity of tested material and making the possibility of comparing the results difficult. Therefore, with the intention of allowing statistical tests to be performed, we divided these treatments into 2 large groups of dressings: with and without silver, comparing the outcomes of re-epithelialization and rate of infection of these groups with the outcomes obtained with SSD.

However, it is important to point out that this division was only a device to make it possible to perform statistical tests, because of the large number of dressings with diverse mechanisms used in the RCTs. In the group of dressings without silver, we found the presence of dressings with the function of coverage and debridement and others that functioned as skin substitutes. These skin substitutes protected the wound, artificially re-establishing the integrity of the skin, and consequently reducing fluid loss and the chance of invasion by opportunist microorganisms. In the group of dressings with silver, we found new dressings that associated hydrofiber with silver which was released in a controlled manner in the wound bed. We also found other dressings that associated SSD with other substances such as cerium nitrate or hyaluronic acid, which interfered with the availability of SSD in the wound bed. Thus, the results obtained must be analyzed with caution, considering the variations and difficulties described above.

The methodological quality of the triaged articles was evaluated by means of the CONSORT instrument, and we found that the greatest faults were related to the items that evaluated the research methods. Only $46 \%$ of the items checked were in agreement with the ideal, failing to explain data with reference to the sequence of allocation, masking, sample size and methodology for randomization. These failures in describing the method of research increased the chance of bias occurring. Bias is a process at any stage of inference, with the tendency to produce results that systematically move away from the true values. It is any tendency in a collection, analysis, interpretation, publication, or review of data that may lead to conclusions that could systematically be different from the truth.

When we analyzed the risk of bias of our sample according to the Cochrane Handbook for interventions of systematic reviews [9], we observed that the results were in agreement with the data demonstrated in the CONSORT analysis. The highest risk of bias rates were found in the generation of the randomization sequence (approximately 50\% uncertain risk of bias), in concealment of allocation (62\% uncertain risk of bias), and in masking of participants $(80 \%$ high or uncertain risk of 


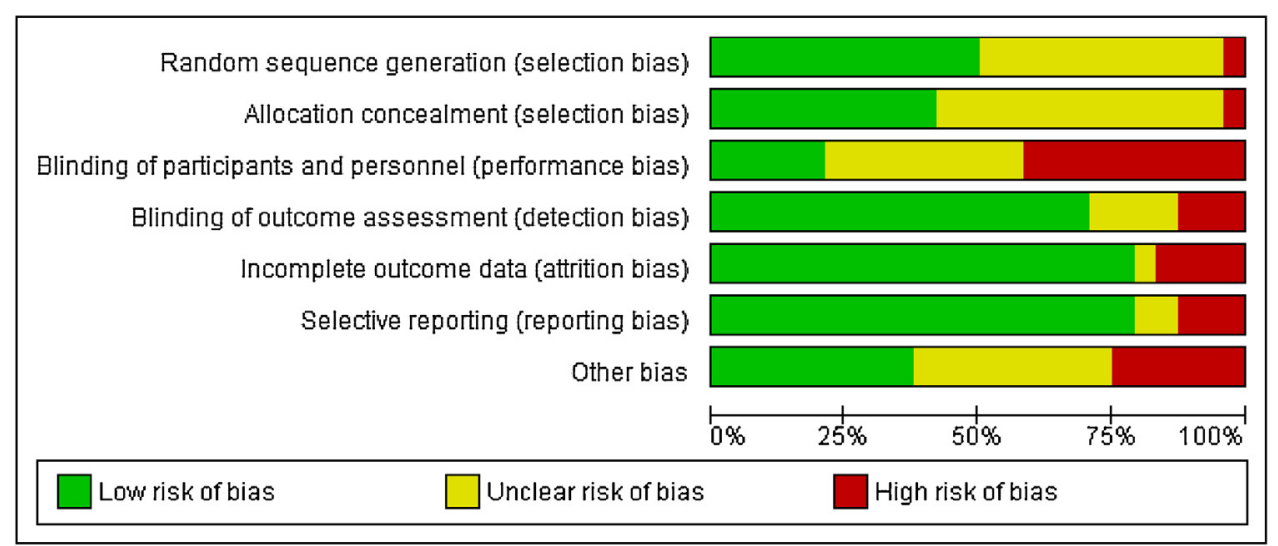

Fig. 2-Graph showing quality of risk of bias: judgment of the authors' review about each item present by means of percentage of studies included.

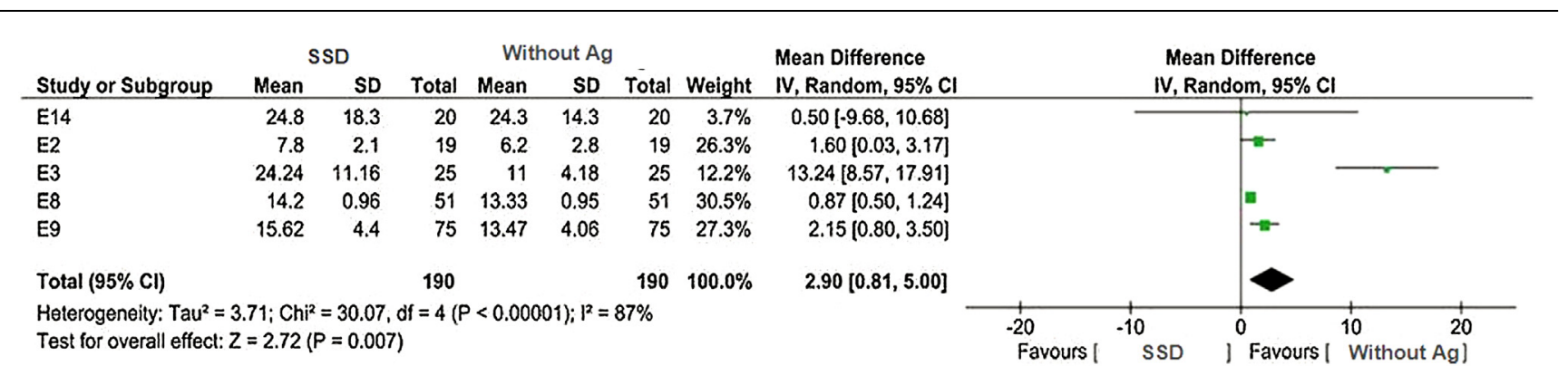

Fig. 3 - SSD $\mathrm{X}$ dressings without silver.

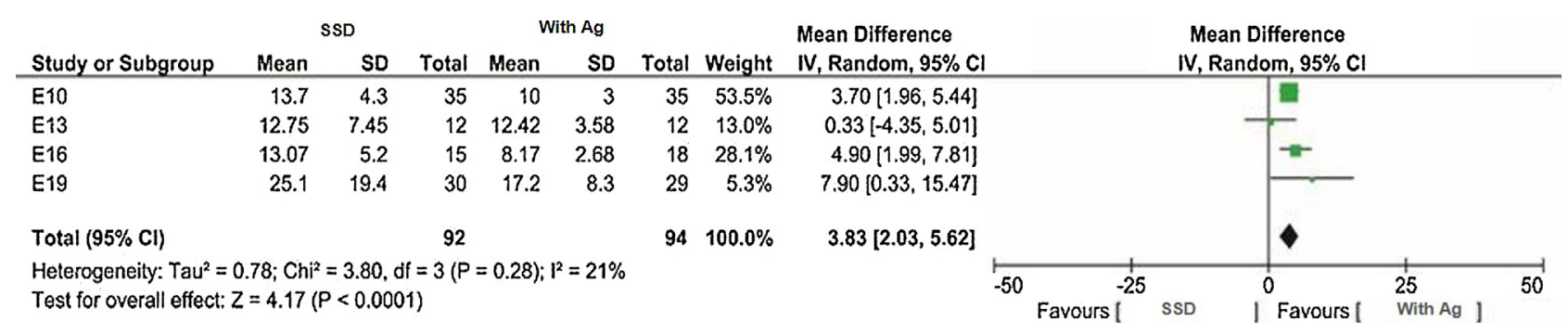

Fig. 4 - SSD X dressings with silver.

bias); that is, all factors that indicated failure in methodological planning.

The failures in generating the random sequence and concealing allocation indicated mistakes in the process of randomization of the study participants. In general, the studies only cited that there was randomization, but they did not detail the manner in which the process was performed, generating a doubt about whether this omission occurred due to lack of care when writing the article, or due to failures in the randomization process. The ideal would be for clinical trials to use computed randomization methods with minimal intervention of the researchers to reduce the risks of errors [40].

Blinding was the factor with the highest risk of bias rate, since only $18 \%$ of the studies adequately described the measures for masking information from the participants, however, this result could not be considered surprising. A great difficulty in clinical trials testing wound dressings is to achieve complete masking of those who apply the dressings, and particularly, of the patients who receive the products. No matter how much effort is made to provide 2 ointments or creams with the same appearance, there is always some type of minimal difference in consistency, color, odor, or other characteristic that will, over the course of time, allow patients and researchers to discover the identity of the drug they are using.

Another important aspect observed in both CONSORT and in the risk of bias evaluation was financial support. Although almost all the studies compared SSD with commercial products, the majority of the articles did not cite whether or 
not they received financial support for conducting the research. The absence of this type of information may generate doubts toward the reliability of the data presented in the clinical trial, as well as allow the possibility for ethical questioning about the study.

With regard to the meta-analysis, many studies had to be excluded from the final sample because they did not provide all the data (mainly standard deviation of re-epithelialization) for performing statistical analysis. This is another point that deserves the attention of researchers, the presentation of statistical data of a study must be made in the most complete manner possible, because these data may allow other authors to answer new research questions.

When observing the graph in Fig. 4, we noted that the wounds treated with silver dressing presented a more rapid re-epithelialization than the wounds treated with SSD. This fact may be explained by the vehicle used to deliver the silver to the wound which causes SSD to be released rapidly and in large quantity, leading to the rapid loss of silver ions. This causes the patient trauma and discomfort, with significant pain and need of parenteral analgesia and anesthesia, which interfere with eating, mood, and general level of activity; whereas in the dressing with silver, the release occurs more slowly and in small quantities, presenting a lower level of toxicity to the cells of the wound $[7,41]$.

On the other hand, in Fig. 3, when we compared SSD with dressings without silver, we observed an even more favorable statistical difference for the group without silver; that is, wounds with dressings without silver healed in a shorter space of time. This finding corroborates those of studies that demonstrated the toxicity of silver in cells of the wound, and the consequent harm to re-epithelialization of the lesions [41-43]. Moreover, it is worth mentioning that among the dressings without silver, we found an RCT that used a skin substitute (amniotic membrane - E8). This type of material releases growth factors that stimulate the migration of keratinocytes, accelerating the process of re-epithelialization.

With regard to the outcome of infection, it should be noted that this was an important limitation of the study. Few studies could be selected, with the majority being of poor quality and the data being presented very succinctly, without very detailed information. Therefore, analysis of the results of this outcome must be made most cautiously, because the studies available in the literature, to date, did not allow a definitive conclusion with regard to the effect of SSD on infection prevention.

Only in the comparison between SSD and dressings without silver was it possible to obtain results with statistical significance, showing a lower rate of infection in the group who received dressings without silver. Innumerable clinical studies have shown the positive effects of silver as a bactericide, however, in the results compiled from the clinical trials evaluating burn treatments, it was not possible to prove its capacity to prevent infection. This finding appeared to be in marked contrast to the results found in the RCTs regarding the prevention of infection. The superior result of dressings without silver was perhaps owing to the fact that these dressings accelerated re-epithelialization, reduced the period of time in which the wound remained open, and consequently diminished the time for bacterial invasion. Another possible confounding factor was the presence of skin substitutes in the group of dressings without silver. The primary function of these biomaterials is to replace the protective barrier of skin and prevent invasion of the wound by bacteria. One of the studies (E12), that evaluated the outcome of infection, used Xenoderm, a skin substitute prepared from a porcine source.

An important limitation of this study is the low number of randomized controlled trials $(n=8)$ that evaluates both outcomes simultaneously, this factor undermines the power of the conclusions. The other 16 selected clinical trials evaluated only one outcome, missing the opportunity to evaluate both outcomes in the same patient group.

In clinical practice, we have been able to observe the consolidated use of SSD as an antimicrobial agent in the control of infections in burns; it is the treatment of choice in the majority of burn-treatment centers. However in this study, the meta-analysis showed that when SSD was compared with other types of dressings, it harmed the process of reepithelialization. Therefore, the widespread use of SSD deserves to be questioned by health professionals, due to the likelihood of it not being the best therapeutic option available for the treatment of burns.

\section{Conclusion}

The authors concluded that there were new dressings (with or without silver) which show better results than SSD on the outcome of wound healing, reducing the time necessary to restore burn lesions. There is immediate need for conducting RCTs with adequate methodological quality and high statistical power to investigate the effectiveness of SSD and silver dressings for preventing infection in patients with burns.

\section{Conflict of interest}

None of the authors has to disclose any conflict of interest.

R E F E R E N C E S

[1] Hettiaratchy S, Dziewuslki P. Pathophysiology and types of burns. BMJ 2004;328(June (74530)):1427-9, doi:http://dx.doi.org/ 10.1136/bmj.328.7453.1427.

[2] Saffle JR, Davis B, Williams P. Recent outcomes in the treatment of burn injury in the United States: a report from the American burn association patient registry. J Burn Care Rehabil 1995;16(3 Pt 1):219-32.

[3] Greenhalgh DG. Topical antimicrobial agentes for burn wounds. Clin Plast Surg 2009;36(October (4)):597-606, doi: http://dx.doi.org/10.1016/j.cps.2009.05.011.

[4] Fox Jr. CL. Pharmacology and clinical use of silver sulfadiazine and related topical antimicrobial agentes. Pahlavi Med J 1977;8 (January (1)):45-64.

[5] Storm-Versloot MN, Vos CG, Ubbink DT, Vermeulen H. Topical silver for preventing wound infection. Cochrane Database Syst Rev 2010;17(March (3)):CD006478, doi:http://dx.doi.org/ 10.1002/14651858.CD006478.

[6] Hussain S, Ferguson C. Best evidence topic report: silver sulphadiazine cream in burns. Emerg Med J 2006;23(December 12):929-32.

[7] Hajská M, Slobodniková L, Hupková H, Koller J. In vitro efficacy of various topical antimicrobial agents in different time 
periods from contamination to application against 6 multidrug-resistant bacterial strains isolated from burn patients. Burns 2014;40:713-8.

[8] Kempf M, Kimble RM, Cuttle L. Cytotoxicity testing of burn wound dressings, ointments and creams: a method using polycarbonate cell culture inserts on a cell culture system. Burns 2011;37:994-1000.

[9] Moher D, Liberati A, Tetzlaff J, Altman DG, The PRISMA Group. Preferred reporting items for systematic reviews and metaanalyses: the PRISMA statement. PLoS Med 2009;6(7): e1000097, doi:http://dx.doi.org/10.1371/journal.pmed1000097.

[10] Agoritsas T, Merglen A, Courvoisier DS, Combercure C, Garin N, Perrier A, et al. Sensitivity and predictive value of 15 Pubmed search strategies to answer clinical questions rated against full systematic reviews. J Med Internet Res 2012;14 (June (3)):e85, doi:http://dx.doi.org/10.2196/jmir.2021.

[11] Higgins JPT, Green S. Cochrane handbook for systematic reviews of interventions. Version 5.1.0 (updated March 2008). The Cochrane Collaboration; 2011.

[12] Campbell MK, Piaggio G, Elbourne DR, Altman DG. Consort 2010 statement: extension to cluster randomized trials. BMJ 2012345:. http://doi.org/bmj.e5661.

[13] Tang H, Xiaodong C, Jin L, Hongyan Q, Zhao FX. An open, parallel, randomized, comparative, multicenter investigation evaluating the efficacy and tolerability of Mepilex Ag versus silver sulfadiazine in the treatment of deep partial-thickness burn injuries. J Trauma Acute Care Surg 2015;78(5):1000-7.

[14] Glenn ASG, Kathrina VBA, Andre PT, Lapitan MCM, Brian SB. Topical petrolatum gel alone versus topical silver sulfadiazine with standard gauze dressings for the treatment of superficial partial thickness burns in adults: a randomized controlled trial. Burns 2014;40:1267-73.

[15] Muhammad NS, Naheed A. Effectiveness of aloe vera gel compared with $1 \%$ silver sulphadiazine cream as burn wound dressing in second degree burns. J Pak Med Assoc 2013;63 (2):225-30.

[16] Oen IMMH, Baar MEV, Middelkoop E, Nieuwenhuis MK. Effectiveness of cerium nitrate-silver sulfadiazine in the treatment of facial burns: a multicenter, randomized, controlled trial. Plast Reconstr Surg 2012;130(2):274-83.

[17] Ostlie DJ, Juang D, Aguayo P, Pettiford-Cunningham JP, Erkmann EA, Rash DE, et al. Topical silver sulfadiazine vs collagenase ointment for the treatment of partial thickness burns in children: a prospective randomized trial. J Pediatr Surg 2012;47:1204-7.

[18] Silverstein P, Heimbach D, Meites H, Latenser B, Mozingo D, Mullins F, et al. An open, parallel, randomized comparative, multicenter study to evaluate the cost-ffectiveness, performance, tolerance, and safety of a silver-containing soft silicone foam dressing (intervention) vs silver sulfadiazine cream. J Burn Care Res 2011;617-26.

[19] Piatkowski A, Drummer N, Andriessen A, Ulrich D, Pallua N. Randomized controlled single center study comparing a polyhexanide containing bio-cellulose dressing with silver sulfadiazine cream in partial-thickness dermal burns. Burns 2011;37:800-4.

[20] Mostaque AAK, Rahman KBMA. Comparisons of the effects of biological membrane (amnion) and silver sulfadiazine in the management of burn wounds in children. J Burn Care Res 2011;32(2):200-9.

[21] Malik KI, Malik MAN, Aslam A. Honey compared with silver sulphadiazine in the treatment of superficial partial-thickness burns. Int Wound J 2010;7(5):413-7.

[22] Muangman S, Pornprom M, Chanin P, Supaporn O. A prospective, randomized trial of silver containing hydrofiber dressing versus $1 \%$ silver sulfadiazine for the treatment of partial thickness burns. Int Wound J 2010;7(4):271-6.
[23] Grippaudo FR, Carini L, Baldini R. ProcutaseW versus 1\% silver sulphadiazine in the treatment of minor burns. Burns 2010;36:871-5.

[24] Hosseini SN, Karimian A, Mousavinasab SN, Rahmanpour H, Yamini M, Zahmatkesh SH. Xenoderm versus 1\% silver sulfadiazine in partial-thickness burns. Asian J Surg 2009;32 (4):234-9.

[25] Glat PM, Kubat WD, Hsu JF, Copty T, Burkey BA, Davis W, et al. Randomized clinical study of Silvasorb ${ }^{\text {Ti }}$ gel in comparison to Silvadene ${ }^{10}$ silver sulfadiazine cream in the management of partial-thickness burns. J Burn Care Res 2009;30:262-267.

[26] Hirsch T, Ashkar W, Schumacher O, Steinstraesser L, Ingianni G, Cedidi C. Moist exposed burn ointment (mebo) in partial thickness burns a randomized, comparative open monocenter study on the efficacy of dermaheal (mebo) ointment on thermal 2nd degree burns compared to conventional therapy. Eur J Med Res 2008;13:505-10.

[27] Caruso DM, Foster KN, Blome-Eberwein SA, Twomey JA, Herndon DN, Luterman A. Randomized clinical study of hydrofiber dressing with silver or silver sulfadiazine in the management of partial-thickness burns. J Burn Care Res 2006;27:298-309.

[28] Koller J. Topical treatment of partial thickness burns by silver sulfadiazine plus hialuronic acid compared to silver sulfadiazine alone: a double-blind, clinical study. Drugs Exp Clin Res 2004;5(6):183-90.

[29] Carneiro PMR, Rwanyuma LRJ, Mkony CA. A comparison of topical phenytoin with silverex in the treatment of superficial dermal burnwounds. Cent Afr J Med 2002;48(9):105-8.

[30] Scott RG, Piccolo N, Piccolo MT, Piccolo MS, Heggers JP. Comparison of propolis skin cream to silver sulfadiazine: a naturopathic alternative to antibiotics in treatment of minor burns. J Altern Complement Med 2002;8(1):77-83.

[31] Gracia CG. An open study comparing topical silver sulfadiazine and topical silver sulfadiazine-cerium nitrate in the treatment of moderate and severe burns. Burns 2001;67-74

[32] Lal S, Barrow RE, Wolf SE, Chinkes DL, Hart DW, Heggers JP, et al. Biobrane improves wound healing in burned children without increased risk of infection. Shock 2000;14(3):314-9.

[33] Barret JP, Dziewulski FRCS, Ramzy PI, Wolf SE, Desai MH, Herndon DN. Biobrane versus 1\% silver sulfadiazine in second-degree pediatric burns. Plast Reconstr Surg 2000;105 (1):62-5.

[34] Kumar JR, Kimble RM, Boots R, Pegg SP. Treatment of partialthickness burns: a prospective, randomized trial using transcyte. ANZ J Surg 2004;74:622-6.

[35] Huang Y, Xiaolu Li, Zhenjiang L, Guoan Z, Qun L, Tang J, et al. A randomized comparative trial between acticoat and SD-Ag in the treatment of residual burn wounds, including safety analysis. Burns 2007;33:161-6, doi:http://dx.doi.org/10.1016/j. burns.2006.06.020.

[36] Nasiri E, Hosseinimehr S, Hosseinzadeh A, Azadbakht M, Akbari J, Azadbakht M. The effects of Arnebia euchroma ointment on second-degree burn wounds: a randomized clinical trial. J Ethnopharmacol 2016;189:107-16, doi:http://dx. doi.org/10.1016/j.jep.2016.05.029.

[37] Peden M, Oyegbite K, Ozanne-Smith J, Hyder AA, Branche C, Rahman AKMF, et al. Burn. World report on child injury prevention. Geneve: World Health Organization; 2008. p. 79-94.

[38] Garcia AP, Pollo V, Souza JA, Araujo EJ, Feijó R, Pereima MJL. Análise do método clínico no diagnóstico diferencial entre queimaduras de espessura parcial e total. Rev Bras Queimaduras 2011;10(2):42-9.

[39] Forjuoh SN. Burns in low-and middle-income countries: a review of available literature on descriptive epidemiology, risk factors, treatment, and prevention. Burns 2006;32(5):529-37. 
[40] Carvalho AP, Silva V, Grande AJ. Avaliação do risco de viés de ensaios clínicos randomizados pela ferramenta da colaboração Cochrane. Diagn Tratamento 2013;18(1):38-44.

[41] Kempf M, Kimble RM, Cuttle L. Cytotoxicity testing of burn wound dressings, ointments and creams: a method using polycarbonate cell culture inserts on a cell culture system. Burns 2011;37:994-1000.

[42] Holmes AM, Lim J, Studier H, Roberts MS. Varying the morphology of silver nanoparticles results in differential toxicity against micro-organisms, $\mathrm{HaCaT}$ keratinocytes and affects skin deposition. Nanotoxicology 2016;10(December (10)):1503-14.

[43] Galandáková A, Franková J, Ambrožová N, Habartová K, Pivodová V, Zálešák B, et al. Effects of silver nanoparticles on human dermal fibroblasts and epidermal keratinocytes. Hum Exp Toxicol 2016;35(September (9)):946-57, doi:http://dx.doi. org/10.1177/0960327115611969. 